\title{
Citizen observatories of water: Social innovation via eParticipation?
}

\author{
Uta Wehn and Jaap Evers \\ Integrated Water Systems and Governance Department \\ UNESCO-IHE \\ Delft, The Netherlands \\ u.wehn@unesco-ihe.org \\ j.evers@unesco-ihe.org
}

\begin{abstract}
We live in the age of Big Data, yet many areas of environmental management are still suffering from a lack of relevant data, information and knowledge that impedes sound decision making. A highly relevant phenomenon is therefore the so-called citizen observatories whereby the observations of ordinary citizens, and not just those of professionals and scientists, are included in earth observation and environmental conservation. Advanced citizen observatories can enable a twoway communication paradigm between citizens and decision makers, potentially resulting in profound changes to existing flood risk management processes and, as such, in social innovation processes and outcomes. This paper analyses the social innovation potential of such ICT-enabled citizen observatories to increase eParticipation in local governance processes related to flood risk management. The findings from empirical research in two case study locations highlight the divergent roles that authorities conceive for citizens and the role(s) that citizens in practice assign to themselves. A challenge for citizen observatories is therefore to consider the extent to which the (in some cases) essential, continuous face-to-face contact and relationship-building between authorities and citizens can be moved to, or complemented with, functionalities in the online sphere of the observatories. Moreover, given the institutional structures identified in these cases and the obligation of authorities to be accountable for their decisions, citizen observatories do not automatically imply that citizens will have a higher level of participation in planning and decision making, nor that communication between stakeholders improves. As long as flood risks are perceived as an issue that should be dealt with by the authorities, there will be little motivation for citizens to participate.
\end{abstract}

Index Terms - social innovation, citizen observatory, eParticipation, governance, two-way communication, flood risk management, disaster cycle

\section{INTRODUCTION}

We live in the age of Big Data, yet many areas of environmental management are still suffering from a lack of relevant data, information and knowledge that impedes sound decision making. A highly relevant phenomenon is therefore the so-called citizen observatories whereby the observations of ordinary citizens, and not just those of scientists and professionals, are included in earth observation and environmental conservation. The basic idea of involving the public in data gathering has been termed 'citizen science' by natural scientists [e.g. 1, 2], 'volunteered geographic information' [3] and 'crowdsourcing geospatial data' [4] by geographers and 'people-centric sensing' [5] and 'participatory sensing' [6] by computer scientists. Citizen observatories can have many 'shapes and sizes', often extending beyond 'mere' data collection and sensing to citizen participation in decision making. They vary, for example, in terms of their area of application (from observing the physical environment to human behavior), involving implicit or explicit data provision, collecting objective or subjective measurements, from bottom up to top down implementation, and using uni- or bi-directional communication paradigms between citizens and data 'processors'[7] (see Table 1).

TABLE I. DIMENSIONS OF CITIZEN OBSERVATORIES

\begin{tabular}{|c|c|c|c|}
\hline Dimensions & \multicolumn{3}{|c|}{ Range } \\
\hline $\begin{array}{l}\text { Sensors \& } \\
\text { transmission }\end{array}$ & Physical sensor & & Social sensor \\
\hline Stakeholders & Authorities & & Citizens \\
\hline Area of application & $\begin{array}{l}\begin{array}{l}\text { Physical } \\
\text { environment }\end{array} \\
\end{array}$ & & $\begin{array}{r}\text { Human } \\
\text { behaviour }\end{array}$ \\
\hline $\begin{array}{l}\text { Purpose of citizen } \\
\text { observatory }\end{array}$ & $\begin{array}{l}\text { Protect } \\
\text { environment }\end{array}$ & & $\begin{array}{l}\text { Strengthen } \\
\text { governance }\end{array}$ \\
\hline Integration & Stand-alone & 4 & Integrated \\
\hline Measurement & Objective & & Subjective \\
\hline Implementation & Bottom up & 4 & Top-down \\
\hline $\begin{array}{l}\text { Communication } \\
\text { paradigm }\end{array}$ & Uni-directional & & Bi-directional \\
\hline $\begin{array}{l}\text { Citizen } \\
\text { participation in }\end{array}$ & $\begin{array}{l}\text { Implicit data } \\
\text { provision }\end{array}$ & & $\begin{array}{l}\text { Technical } \\
\text { expertise }\end{array}$ \\
\hline $\begin{array}{l}\text { governance } \\
\text { processes }\end{array}$ & $\begin{array}{l}\text { Individual } \\
\text { education }\end{array}$ & & $\begin{array}{r}\text { Direct } \\
\text { authority }\end{array}$ \\
\hline
\end{tabular}

The citizen observatories of water being developed by the WeSenseIt project go beyond 'mere' sensing in order to harness environmental data and knowledge to effectively and efficiently manage water resources. The key aspect of the observatories of the WeSenseIt project is the direct involvement of user communities in the data collection process: it enables citizen involvement collecting data via an innovative combination of easy-to-use sensors and monitoring technologies as well as harnessing citizens' collective intelligence, i.e. the information, experience and knowledge 
embodied within individuals and communities (e.g. using apps and social media). In a virtual web-based and mobile place, the e-collaboration platform, data and information can be gathered, shared and contextualised to provide up-to-date situation awareness. The developed platform will be in synergy with global data sharing initiatives complementary to the actions conducted under the GMES initiative; all data and selected components will be made available within the GEOSS framework.

Next to the technological innovations and the resulting improved density of information available for environmental management, the citizen observatories of water present the potential for considerable improvements in terms of social innovations. Their features can enable a two-way communication paradigm between citizens and decision makers, potentially resulting in profound changes to existing flood risk management processes. Yet due to the emerging nature of citizen observatories, little is known about their implications and how to realize their social innovation potential. In this paper, we focus on one particular social innovation aspect (namely, participation) and we address the following questions: a) what are the current dynamics of citizen participation in existing flood risk management, b) to what extent are they already ICT-enabled, and c) how are these likely to be improved by the citizen observatories of water envisaged by WeSenseIt and their interactive ICT-enabled features?

Drawing on empirical research in the United Kingdom and The Netherlands, we analyse the social innovation potential of citizen observatories for eParticipation in flood risk management. We start with a general discussion of social innovation in Section II to identify the likely types of social innovations related to the WeSenseIt citizen observatories of water. Focusing on participation in political processes in particular, we review and adjust relevant theoretical approaches to serve as a framework for our investigation. In Section III, we present the methodology used for this research while Section IV presents the results for two case study areas. In Section V, we discuss the findings in relation to our research questions, followed by conclusions and recommendations for future research in Section VI.

\section{SOCIAL INNOVATION AND EPARTICIPATION}

Social innovation has been defined in many ways, stemming from different contexts and rationales [8]. Some conceptualizations stress the outcomes of social innovation, arguing that it captures 'societal progress as opposed to economic progress' [9], consisting of new ideas, activities or services that meet social goals or needs [10], is concerned with improving the quality or quantity of life [81], and that it has the nature of a public good [e.g. 11,9]. Others emphasise the social process, regarding social innovation as 'self-conscious collective action that seeks to address the unsatisfied need for sustainable development' [12, p.54]. Yet in principle, social innovation is being considered both, a process and an outcome. Building on the notion of relying on innovation to address social challenges [9], we use the term social innovation here to more specifically refer to the desirable outcomes of a technological innovation for social or societal benefits (as opposed to profit maximization). As the social studies of technology literature has long argued, desirable outcomes of technological innovations are not intrinsic and therefore do not necessarily occur automatically [e.g. 1]. Hence it is important to define what the social innovation in question consists of, to what extent it is being attained and under what conditions, and how it can be fostered. In the current case of citizen observatories of water with their focus on flood risk management, the social innovation of these observatories may span expected societal benefits ranging from generally improving sustainability, to fostering the resilience of communities, to - more specifically still - enhancing governance processes (e.g. in terms of transparency and participation). In this paper, we focus on one specific social innovation aspect of citizen observatories, namely eParticipation in governance processes.

Participation in decision making is of course not a new concept. Based on a literature review of stakeholder (rather than broader public) participation in decision making, Reed [14] argues that participation approaches have progressed through a series of phases: awareness raising in the 1960s, incorporation of local perspectives in the 1970s, recognition of local knowledge in the 1980s, participation as a norm as part of the sustainable development agenda of the 1990s, subsequent critiques and recently a 'post-participation' consensus regarding best practice. Arnstein's [15] seminal article 'The ladder of citizen participation' from the late sixties serves as a starting point for most debates on citizen participation. She ranged different levels of participation along an eight point scale, or 'ladder', ranging from manipulation (the lowest in the group of non-participation steps) to citizen control (the highest step; also the highest degree of citizen power). The usefulness of this distinction is debatable and has been criticised for implying that it conceptualises participation as an ends rather than a means. Specifically, Fung [16] argues that the ladder mixes empirical scaling with normative approval while excluding important elements of the context and, therefore, the desirability within which participation may take place. It also does not take into account links between a) the goals of involvement, b) those who actually participate and c) the ways in which they are invited to participate [17]. Fung [16] proposed an alternative to the ladder of citizen participation, distinguishing between three dimensions of public decision mechanisms (which he called the 'democracy cube'), namely a) the scope of participation (who participates: from government representatives to the general public (citizens), b) the mode of communication and decision (how participants interact and what role they play), and c) the extent of authority (participation for personal benefit only (such as individual education), up to direct authority).

Due to the rapid and wide diffusion of information and communication technologies (ICTs), new means for participation in political processes have becomes available which are captured by the concept of electronic participation (eParticipation). 


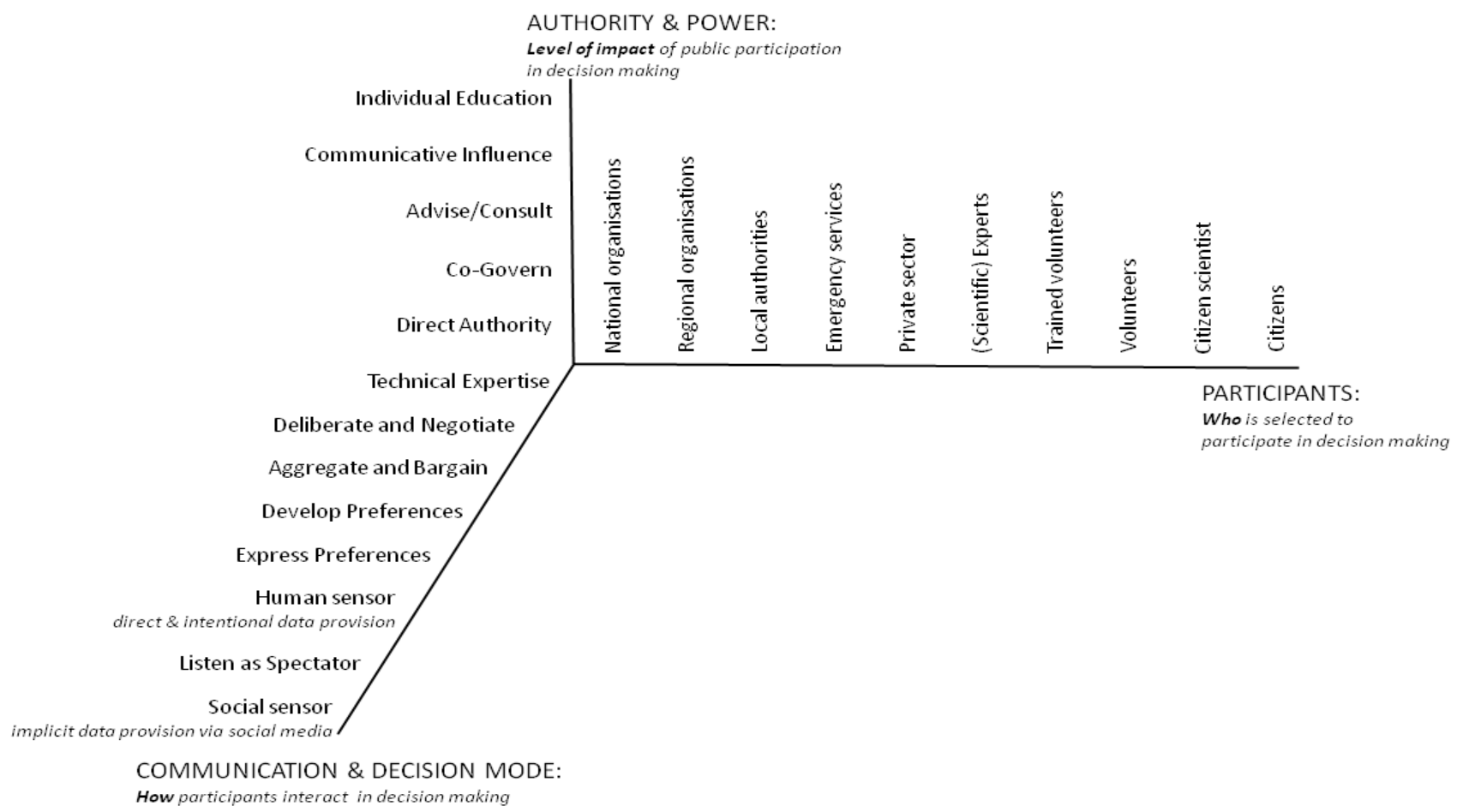

Fig. 1. The democracy cube for citizen participation in decision making on flood risk management. Source: adjusted from [16]

While substantive reviews $[18,19,20]$ serve to capture and indicate the progress that is being made by research on eParticipation, the field is still suffering from a lacking of sound theoretical approaches. Moreover, Sandford and Rose [18] conclude that dedicated eParticipation technology does not seem to exist; a whole range of ICTs have the potential to serve eParticipation purposes (e.g. from eVoting, data mining, the semantic web, geographic information systems (GIS) and other visualization technology, and virtual meeting places (such as chat rooms and online fora)). In the field of GIS in particular, Participatory GIS (P-GIS) approaches refer to public participation in decision making facilitated or mediated by the use of GIS (focusing primarily on planning processes). P-GIS is expected to address both, concerns regarding the (often lacking) a) public participation in spatial decision making as raised e.g. by [21] and b) involvement of communities in creating, verifying and working with geographic information. Conceptualizations of public participation in this field still rely largely on Arnstein's one-dimensional ladder of participation [e.g. 22, 23, 24, 25]. Moreover, the effectiveness of P-GIS for eParticipation is still questionable [22].

The citizen observatories of water developed by WeSenseIt will not be different in that respect; rather, the question is how (or under what conditions) the combination of new and existing sensing and monitoring technologies together with other interactive ICTs (apps and social media), provided by the WeSenseIt citizen observatories can serve to foster eParticipation. While action research accompanies the entire process of designing, implementing and evaluating these citizen observatories of water $^{1}$, in this paper, we focus on the contextual variables that are seemingly still neglected in much of eParticipation research [20]. Specifically, we consider to what extent participation in existing governance processes is likely to be improved by the citizen observatories of water envisaged by WeSenseIt and their interactive ICT-enabled features. For this purpose, we build on the political science approach to participation discussed above and adjust the democracy cube so as to have a means to analyse the distinct participation mechanisms of the two citizen observatories according to a common classification scheme. The resulting (adjusted) democracy cube is presented in Figure 1.

Specifically, the 'communication and decision scale' is completed in line with the WeSenseIt-enabled social sensor possibilities so that the scale adequately captures the means of interaction and the roles that participants can play in decision making. A 'social sensor' role refers to citizen observations collected and mined from social media without citizens necessarily realising that their observation about a local situation is being included in a decision making process. Secondly, the category 'human sensor' is included to capture the intended and volunteered observations by citizens, collected using photos, videos, or sensor technology. Secondly, Fung's [16] 'scope of participation' dimension is adjusted to the specific stakeholders that may be involved in flood risk management and governance (ranging from citizens, citizen scientists, volunteers and trained volunteers, to various types of public sector institutions). With the citizen observatories of water currently being set up, this paper analyses the current

\footnotetext{
${ }^{1}$ Preliminary results were presented in [30].
} 
dynamics of citizen participation in decision making, the extent to which these processes are already ICT-enabled, and how these are likely to be improved by the interactive ICT-enabled features of the citizen observatories of water envisaged by WeSenseIt. We do so by analyzing the current participation modes and the current use of ICTs in these processes (i.e. the extent of current eParticipation). Future research will consist of an evaluation to assess the longer term effects and implications the citizen observatories in terms of eParticipation.

\section{METHODOLOGY}

The WeSenseIt citizen observatories of water are being tested and validated in several case studies in collaboration with water management and civil protection agencies. Their roles and their interactions with citizens during different phases of the disaster cycle (consisting of preparation, response, recovery, mitigation/prevention [26]) were mapped for two WeSenseIt cases (in the UK and The Netherlands) to understand how stakeholders interact in the decision making processes related to flood risk management. In particular, the methodology of this research consists of action research in the two locations. This paper reports on research undertaken during the planning phase of the citizen observatories, i.e. before implementation and resulting changes. The concepts introduced in section I (adjusted democracy cube, current use of ICTs) were operationalised by translating them into questions for desk research and interviews and relating them to the different phases of the disaster cycle.

TABLE II. OVERVIEW OF FLOOD RISK-RELATED INTERVIEWS

\begin{tabular}{|c|c|c|}
\hline & \multicolumn{2}{|c|}{ Case studies } \\
\hline & Doncaster (UK) & Delfland (NL) \\
\hline \multicolumn{3}{|c|}{ Local authority } \\
\hline $\begin{array}{l}\text { Emergency/ } \\
\text { crisis }\end{array}$ & $\begin{array}{l}\text { Doncaster Metropolitan } \\
\text { Borough Council (DBMC) } \\
\text { Resilience and Emergency } \\
\text { Planning Manager }\end{array}$ & $\begin{array}{l}\text { Westland Policy advisor } \\
\text { Public spaces and security }\end{array}$ \\
\hline Planning & $\begin{array}{l}\text { DBMC Environmental } \\
\text { planning manager }\end{array}$ & $\begin{array}{l}\text { Westland: Policy advisor } \\
\text { Spatial Development and } \\
\text { water }\end{array}$ \\
\hline $\begin{array}{l}\text { Infra- } \\
\text { structure }\end{array}$ & $\begin{array}{l}\text { - DBMC: Drainage } \\
\text { engineer, Flood Risk } \\
\text { and Engineering } \\
\text { - Drainage Board: Senior } \\
\text { Drainage Engineer }\end{array}$ & \\
\hline $\begin{array}{l}\text { Policy } \\
\text { making }\end{array}$ & Elected councilor & \\
\hline \multicolumn{3}{|c|}{ Regional authority } \\
\hline Emergency & $\begin{array}{l}\text { - South Yorkshire (SY) } \\
\text { Fire \& Rescue: station } \\
\text { manager } \\
\text { - SY Police: Contingency } \\
\text { planning officer }\end{array}$ & $\begin{array}{l}\text { - Water Authority (WA) } \\
\text { Delfland: Policy advisor } \\
\text { Crises control and } \\
\text { management } \\
\text { - WA Delfland: Team } \\
\text { leader Crises and } \\
\text { communication } \\
\end{array}$ \\
\hline Planning & - & $\begin{array}{l}\text { WA Delfland: Team } \\
\text { leader spatial development }\end{array}$ \\
\hline $\begin{array}{l}\text { Infra- } \\
\text { structure }\end{array}$ & - & $\begin{array}{l}\text { WA Delfland: Team } \\
\text { leader maintenance water } \\
\text { infrastructure }\end{array}$ \\
\hline $\begin{array}{l}\text { National } \\
\text { authority }\end{array}$ & $\begin{array}{l}\text { Environment Agency: } \\
\text { Senior Advisor }\end{array}$ & - \\
\hline
\end{tabular}

Empirical research was carried out in May and June 2013. This relied on a protocol for semi-structured interviews that were held with relevant local authorities, emergency services as well as regional (and, incidentally, national) policy makers. In total, 14 extensive face-to-face interviews were conducted. Table 2 presents an overview of the stakeholders interviewed for each case. These span leading staff for emergency and crisis control, planning as well as infrastructure maintenance at the local level, planning and emergency services at the regional level and (in the UK) the Environment Agency at the national level. The transcribed interviews were analysed according to the framework introduced in the previous sections and the collected data triangulated with information from desk research, such as country reports about the implementation of relevant EU Directives (incl. the Water Framework Directive, Flood Directive) and the Aarhus Convention.

\section{CASE STUDIES}

In this section, each case is briefly introduced in terms of its geographic setting and flood-related history; then the findings on citizen participation in decision making are presented, together with an analysis of the use of ICTs in these processes.

\section{A. The Doncaster case study (UK)}

\section{1) Case introduction}

The city of Doncaster is located in the county of South Yorkshire in England, along the river Don. This town has suffered from significant flooding events over many years, including the large-scale floods in 2007 that affected much of the United Kingdom. Both, the topography of the county of South Yorkshire and its network of river catchments contribute to the flood risk of this region. It is liable to fluvial (river), pluvial (rain induced) and marine (sea) flooding caused by heavy rainfall in the catchment of the river Don and tidal fluctuations and potential floods from dam failure in the valleys to the North and West of the county (which contain 17 major reservoir dams). Doncaster Metropolitan Borough has some 320,000 inhabitants; some 25,000 properties are currently at risk from river Don flooding.

\section{2) Citizen participation in flood risk management}

The range of formal institutions pertaining to flood risk management in Doncaster is broad, even after the recent consolidation of legislation at the national level. These institutions have implications for which and how different actors involved in flood risk management in Doncaster ${ }^{2}$ collaborate and make decisions related to the different phases of flood risk management. During the preparation, impact and response phases, a strong command and control structure is in place to deal with emergency situations and to draw on necessary resources, if necessary from national government. The drainage board described the citizens as the Council's 'eyes and ears on the ground', providing essential information about the local situation in their role as human sensors.

\footnotetext{
2 i.e. Doncaster Metropolitan Borough Council (DBMC or the Council), the emergency services such as South Yorkshire (SY) police and Fire \& Rescue, the Environment Agency (EA) and the public.
} 
Nevertheless, the authority and degree of impact of citizen participation in this phase is limited to decisions concerning personal safety and the protection of their property. While DMBC and emergency services such as the police can strongly advise citizens to evacuate and leave their property, the ultimate decision rests with the citizens themselves.

During the recovery and mitigation phases, the main drivers for citizen participation consist of a) formal institutions such as the Civil Contingencies Act (2004) and the Local Government Act (2000) which is concerned with the socio-economic wellbeing of local areas as well as having to tie in with national strategies for flood risk and resilience, $b$ ) a drive by the (local) authorities to change the mind set of citizens (from being a customer 'receiving services' to taking responsibility, including for flood risk management) and c) changes in the funding structure that now require various stakeholders to collaborate (EA, local authorities, communities) and present a shift in citizen participation to the start - rather than the end - of the planning process. For example, while the EA's traditional way was to decide what flood risk schemes (e.g. infrastructure investments) needed to be done, then announce these and defend them, more recently, communities are expected to be more involved in the decision making process. For both the $\mathrm{DMBC}$ and the EA, the sequence of the project cycle has therefore changed from 'design - defend - implement' to 'discuss - design - implement'. This presents a shift of the interactions with citizens to the start of the planning process, avoiding confrontation with communities just before project implementation. Moreover, the DMBC planning unit is obliged to demonstrate 'fit for purpose participation' in their planning activities. DMBC is also proactively approaching the communities via the Parish councils and flood wardens (volunteer representatives from the local communities, initiated by the Council following the 2007 floods) to identify their biggest worries or perceived risks. Furthermore, they also talk to 'angry' groups who are thus both empowered and included in the process. During the recovery phase of a flood, public meetings and drop in days are organised at the Council. These meetings present an opportunity to express and develop the citizens' preferences.

More generally, citizen participation consists of a variety of citizen groups (volunteers, elected citizens, citizen scientists and communities) and rests on a range of communication modes (from listening as a spectator to expressing and developing preferences on specific issues). The flood wardens are active in specific, flood-affected areas (neighbourhoods) of Doncaster and involved in the higher level Council and in regional committees. They support the work of both, the EA and $\mathrm{DMBC}$, by reporting and informing on flood-related issues (e.g. obstructions/overgrowing of waterways, etc.) on the basis of regular inspections of the local area. They also function as intermediaries between the Council and the communities for awareness-raising about flood-related issues.

During the recovery and mitigation phases, the role and level of impact in decision making by citizens more generally also extends beyond personal education to 'influential communication' as well as 'advising and consulting', e.g. during the range of community meetings in which South Yorkshire Police, the EA and DMBC seek the communities views and feedback on proposed measures as well as identifying problems and needs in the local areas. These public meetings are (by now) a prominent two-way communication mechanism for awareness-raising as well as gathering information and feedback from flood-affected or at-risk communities about flood risk management and necessary actions, with the overall goal of building trust in the agencies' approach to flood risk management. It is important to note that it took a while to establish these meetings with a critical mass of citizens attending.

The authorities and emergency services all consider the communities and citizens valuable providers of information and insights. Community representatives such as flood wardens (trained volunteers) and citizens elected as councilors are involved in and attend regional committees and as such have the means to have an impact in decision making by influencing agenda setting. Moreover, elected councilors have the authority to approve policy documents related to flood risk management. The range of these inputs is evident from the illustration in Figure 2 (see recovery and prevention phase).

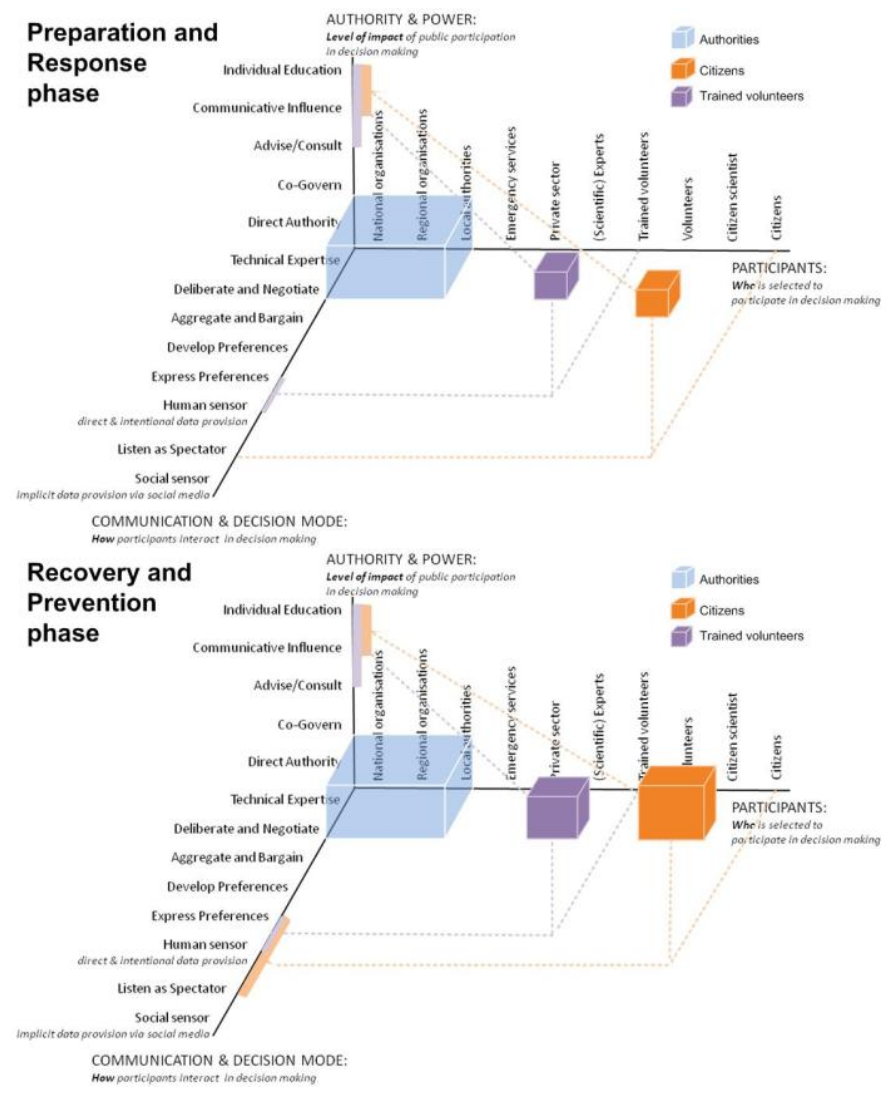

Fig. 2. Citizen participation in decision making in flood risk management Doncaster Case Study

In comparison, during the immediate preparation, impact and response phases, the overall position and influence of citizens in decision making is more limited. The communication modes are more limited, with citizens listening as spectators and acting as human sensors by reporting on the 
local situation. The level of impact of public participation in decision making during this phase is also more limited and more concerned with individuals and communities being informed about the current situation rather than having a say in how the situation should be dealt with.

\section{3) Use of ICTs in participation}

A range of ICTs is currently being used for citizen participation but to a different extent by the various agencies and with differing degrees of uptake by citizens. According to the analysis done by the DMBC Resilience and Emergency Manager in preparation of DMBC's communication strategy with citizens, the strongest impetus for citizens to leave their properties during an emergency arises from their peers (e.g. family members or neighbours) as opposed to official information sources communicated via TV, radio or official websites. Such peer communication can be face-to-face or ICTmediated.

As mentioned above, during the preparation, impact and response phases, the citizens - and the flood wardens in particular - are the 'eyes and ears' of the Council on the ground. Yet especially the flood wardens are almost exclusively senior citizens with little to no familiarity with (advanced) ICTs. Their reporting to the Council relies primarily on traditional fixed line telephones. Nevertheless, the EA provides a free flood warning service, called 'Flood Warnings Direct', via phone, SMS, or email for all citizens, but, according to the EA interviewee, this is not being sufficiently taken up by the public. Part of this service is the phone-based 'Floodline' through which citizens can obtain prerecorded information or via quickdial numbers can speak to the so-called Incident Rooms of a specific geographic area. Twitter feeds are also being used but most of the authorities' interactions with communities and citizens seem to still rely on face-to-face interactions. The interviewee from the EA even suggested that these communications are expected to remain the same in order to really develop relationships between communities and the EA. Certainly for the recovery and mitigation phase, this approach is considered crucial for understanding what is happening with respect to flood risk in the communities. Some problem reporting to the drainage board in Doncaster is being done via email but the majority by telephone.

During the response and recovery phases, the DMBC planning unit makes increasing use of video accounts that were taken during flooding incidents. These short videos by citizens help the DMBC staff considerably with the initial investigation of the situation, often rendering an initial field visit obsolete and thus speeding up the decision making process (and feeding into it). Social media are increasingly being used as a two-way communication mechanism by SY Police, especially in order to counter rumours during emergency situations (not just for flooding). Official responses by the police are then released to counter such rumors, for example via Twitter. During the mitigation phase, social media have apparently not yet been used but may be employed in the future.

A summary of the current use of ICTs during the distinct phases of flood risk management is presented in Table 3.
TABLE III. WHO: WHAT (HOW) - USE OF ICTS FOR PARTICIPATION DURING DIFFERENT PHASES OF FLOOD RISK MANAGEMENT IN THE DONCASTER CASE STUDY

\begin{tabular}{|l|l|}
\hline Preparation phase & Response phase \\
Authorities: & Authorities: \\
- forecasts and warnings for & warnings and updated information \\
citizens (TV, radio, websites, social & for citizens (TV, radio, websites, \\
media, phone, SMS, email) & social media, phone, SMS, email) \\
- counter rumours (social media) & Flood wardens: \\
Flood wardens: & water level reporting (phone) \\
water level reporting (phone) & Citizens: \\
& in/formal reporting of flooding \\
& incidents (digital photos/videos via \\
& email/YouTube) \\
\hline Mitigation/Prevention phase & Recovery phase \\
Authorities: & Authorities: \\
public consultation on policy and & information on damages (TV, radio, \\
flood risk strategy (online document & websites, social media, SMS, email) \\
availability) & Flood wardens: \\
Flood wardens: & water way status (phone) \\
water way obstructions (phone) & Citizens: \\
Citizens: & problem reporting (digital \\
problem reporting/infrastructure & photos/videos phone; YouTube) \\
requests (phone) & \\
\hline
\end{tabular}

\section{B. The Delfland case study (The Netherlands)}

\section{1) Case study introduction}

The water authority Delfland is located in the province of South Holland and is bordered by the North Sea and the Nieuwe Waterweg (New Waterway - main deep water access canal to the Port of Rotterdam). Its administrative area covers amongst others the municipalities of The Hague, and large parts of Rotterdam. The area has a size of 41,000 hectares in which 1.4 million people live and work [27]. It is one of the most densely populated and industrialized areas of the Netherlands. The water authority is tasked with water quantity and quality issues; maintaining safe dikes and dunes (both sea and river based flood control), and operation of several wastewater treatment plants. The Westland municipality is characterized by intensive greenhouse horticulture and is located in the South-Western tip of Delfland.

2) Citizen participation in flood risk management

The Netherlands has a highly institutionalized flood risk management system. Decisions about spatial planning and flood risk management related issues are made by the water board and the municipal council (both are elected bodies). In projects for flood risk management citizens are often informed and heard observers via public meetings, sometimes in workshop settings. Flood risk management is mostly addressed as a technical issue, to be dealt with by (public) professionals rather than citizens. At the same time, citizens expect that flood safety is guaranteed by the authorities. Floods can come to many citizens as a surprise, because of the relative low level of awareness on flood risks. This low level of awareness is the result of both, i) the stance and the ability of the authorities to control (i.e. avoiding) floods rather well, and ii) the citizens not feeling responsible for flood preparedness themselves. The OECD [28] recently presented this "awareness gap" as one of the main challenges for future Dutch water governance. There is limited citizen participation in the preparation and response phases in Delfland, with trained volunteers (the dijkleger; EN: dike army) having a more influential role than other citizens. 
The primary role of citizens in decision making is indirect via elections of the water board (in which voter turnouts are low, at $20 \%$ in 2008). In the densely built-up Delfland area, several projects focus on giving space to water (activities during the prevention phase of the disaster cycle). Stakeholders are more and more involved in these planning and decision making processes, although final decisions are exclusively made by the water board or municipal council. Communication is traditionally unilateral, but via workshops and consultation sessions, stakeholders and citizens are involved for information, advice, or consultation. The level of engagement is, however, not institutionalized (like knowledge sharing, consulting, advising, co-development). It depends on the project context, the project leader and team (and their available time and resources). In the case of spatial/flood risk management projects, citizens are engaged in knowledge provision and consultation. Stakeholders are also able to block flood risk projects during the implementation stage by not cooperating (e.g. by not selling property as required by a particular infrastructural project). As such, their influence is greater than during the planning and decision making phases about flood risk schemes.

The communication department of Delfland is tasked with communicating information to the public and with interpreting and translating specific technical information for non-experts. In Delfland's view, stakeholder participation is only trusted when it is transparent and only works when people are informed in order to play a role in participatory processes (necessitating 'translation' of technical information). In particular, since many citizens seem unaware of the current risk of flooding, they will also be unable to interpret the severity of increased flood risk. This highlights the water authority's perception of having to educate citizens first in order to enable their participation in flood risk management which they consider foremost a technical issue.

During emergencies, citizens do not have a formal role in decision making. The designated mayor coordinates all actions. The water authority is providing technical expertise, and coordinates the dijkleger and contractors in dyke reenforcement emergency activities. Specific disaster information communication happens via local radio and television broadcasting. NL alert can reach all registered cell-phones within a specific geographic area to communicate information (www.NLalert.nl). During disasters, formal communication is currently characterized by its uni-directional flow. Citizens increasingly use social media to report incidents, but these are not part of a two-way communication flow with the authorities.

The interviewees also stressed the importance of gaining better insight into the flood risk perceptions of the inhabitants of specific areas in order to be able to develop better policies and plans for flood risk management. As long as flood risks are perceived as low and as an issue that should be dealt with by the authorities, there will be little motivation for citizens to participate.

During emergencies, several interviewees suggested that there is much room for improvement of communication of the authorities to citizens. Currently, citizens are, in the first instance, regarded as possible victims and not as active disaster managers. However, during a crisis, citizens are the first on the spot to actively provide help in any way they can, whether the authorities approve of it or not.

Although different citizens have different roles in communication and interaction with the authorities (as illustrated in Figure 3), it can be concluded that, in this case, citizens in general are spectators in the interaction with the authorities on flood risk management.

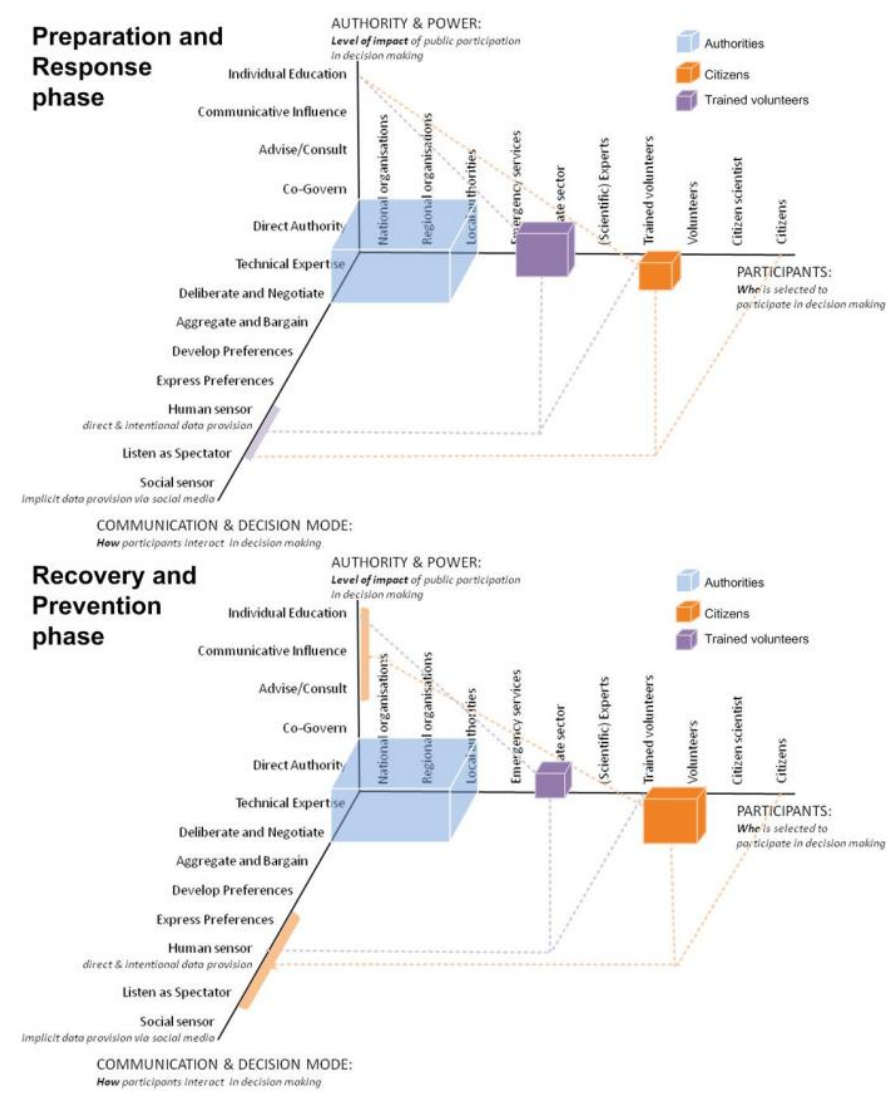

Fig. 3. Citizen participation in decision making in flood risk management Delfland Case Study

\section{3) Use of ICTs in participation}

Both Delfland (the local water board) and Westland (the regional authority) have a website that continuously updates news messages and have social media accounts on Facebook and Twitter. During heavy rainfall in October 2013, the water authority warned two days in advance about the expected weather event. During the flooding period, the water authority installed a crisis centre and continuously updated its news section on the website and communicated via their Twitter account. The water authority did respond to questions and remarks of some citizens via Twitter during this period of high water levels. However, it was merely used for information sharing with citizen Tweeters. During this peak rainfall event, the municipality updated its website less frequently and was also less active on Twitter.

Citizens can also use the website of Delfland to submit official complaints or remarks on specific issues. One interviewee mentioned that this may be extended to mobile 
applications, including the possibility of uploading pictures, since a picture of the water level or a crack in a dyke conveys much more than a written remark. Currently, the water authority reacts as soon as possible to any remark. Based on a photo, the water authority could decide with greater ease and possibly faster about the urgency of required action. Table 4 summarises the current use of ICTs during the distinct phases of flood risk management in this case.

TABLE IV. WHO: WHAT (HOW) - USE OF ICTS FOR PARTICIPATION DURING DIFFERENT PHASES OF FLOOD RISK MANAGEMENT IN THE DELFLAND CASE STUDY

\begin{tabular}{|c|c|}
\hline $\begin{array}{l}\text { Preparation phase } \\
\text { Authorities: } \\
\text { information sharing and awareness } \\
\text { raising on forecast event (TV, radio, } \\
\text { websites, social media, SMS) } \\
\text { Citizens: } \\
\text { reporting maintenance issues and } \\
\text { other potential flood risk problems } \\
\text { (website, email, phone) }\end{array}$ & $\begin{array}{l}\text { Response phase } \\
\text { Authorities: } \\
\text { warnings for citizens (TV, radio, } \\
\text { websites, social media, SMS) } \\
\text { Dijkleger (dike army): } \\
\text { observation and emergency } \\
\text { response for dike inspection and re- } \\
\text { enforcements (phone) } \\
\text { Citizens: } \\
\text { - informal reporting of flooding } \\
\quad \text { incidents (comments and digital } \\
\text { photos/videos via social media) } \\
\text { - formal reporting of flooding } \\
\text { incidents (website of water } \\
\text { authority, email, phone) }\end{array}$ \\
\hline $\begin{array}{l}\text { Mitigation/Prevention phase } \\
\text { Authorities: } \\
\text { public information sharing (online } \\
\text { document availability) } \\
\text { Citizens: } \\
\text { reporting maintenance issues and } \\
\text { other potential flood risk problems } \\
\text { (website, email, phone) }\end{array}$ & $\begin{array}{l}\text { Recovery phase } \\
\text { Authorities: } \\
\text { information on damage and } \\
\text { recovery issues (TV, radio, } \\
\text { websites, social media) } \\
\text { Citizens: } \\
\text { - informal problem reporting } \\
\quad \text { (comments and digital } \\
\text { photos/videos via social media) } \\
\text { - formal problem reporting } \\
\quad \text { (websites of authorities, email, } \\
\text { phone) }\end{array}$ \\
\hline
\end{tabular}

\section{DISCUSSION}

Our findings with respect to the current dynamics of citizen participation in existing flood risk management highlight the divergent roles that authorities conceive for citizens and the role(s) that citizens in practice seem to assign to themselves during the four phases of flood risk management, resulting in specific dynamics of citizen participation in flood risk management in each case:

- In the UK case, citizens are considered as an important stakeholder in flood risk management who need to be engaged in the decision making process to reach consensus. While only elected citizens have intermediate levels of authority and power in the decision making process, the local authorities would like communities and citizens at large to take on a more active role in flood risk management. Efforts are being made to reach specific target groups, to raise awareness on flood risk and its management, and to consult the insights and collective knowledge of communities.

- In the Dutch case, flood risk management is focused on the prevention of floods altogether and not on mitigation and preparedness, with more emphasis on infrastructural maintenance and improvements than the participation and resilience of citizens and communities. Yet, in practice, during disasters, the citizens themselves are 'organized disaster managers', whether the authorities 'like it or not'.

Regarding the extent to which current participation processes are already ICT-enabled, both cases thus far present limited ICT-enabled participation. While digital photo and video reporting of flooding incidents seems to be gaining currency in both cases with similar perceived benefits by the authorities (facilitating and speeding up their processes and possibilities to react, especially during the impact-intense phases), traditional, offline means of communication such as community face-to-face meetings and (fixed line) telephone calls are still very prevalent in both cases. In both cases, these meetings are the moments with the highest impact of citizens on the decision making process: expressing and developing preferences for new plans (in the UK case) or objecting to developed plans near implementation (in the Dutch case) during the mitigation/prevention phase. Nevertheless, citizens are also already participating as human and social sensors, providing observations, comments and photos via social media both directly and intentionally as well as implicitly. The WeSenseIt platform will be able to build on this trend and enhance the efficiency by automating the data mining of social sensor data which is currently still done only incidentally.

The third question posed by our paper concerns how current participation dynamics are likely to be improved by the citizen observatories of water envisaged by the WeSenseIt citizen observatories and their interactive ICT-enabled features (an integrated web-based and mobile environment powered by new sources of aggregated information and two-way communication such as the integration of data captured from various sources, news feeds and alerts about flood warnings during emergencies as well as planning-related documents during mitigation, fora and chats for discussions e.g. about decisions taken during emergencies as well as consultations during the recovery and mitigation phases [29]). The two diverse cases studied here suggest that there are no inherent 'plug and play eParticipation' elements ready to be adopted, confirming earlier findings of the eParticipation literature [14, 19]. The potential of citizen observatories to improve stakeholder engagement and participation in decision making seems to depend on the attitudes and expectations of both, authorities and citizens, as well as the formal division of responsibilities and accountability. In the Dutch case, ICTs are proposed to improve the current system of information sharing between government and citizens, but without real changes in the type of participation (i.e. regarding the role and impact of citizens in decision making). ICTs are thus regarded as means to improve the efficiency and effectiveness of the authority and not as a participation mechanism that grants citizens a more active role in flood risk management. In the UK case, a more active role for citizens in flood risk management is envisaged and encouraged and ICT-enabled data capture by citizens is welcomed. However, the efforts during recent years by the authorities to establish trusted relations with flood-affected 
and/or at-risk communities have resulted in institutionalized community meetings and established flood warden groups. The challenge for the WeSenseIt citizen observatories is therefore to explore whether such essential, continuous face-to-face contact and relationship-building between authorities and citizens can be moved to - or complemented by - functionalities in the online platform of the observatories.

Moreover, along with the (further) development of communication channels, citizens will provide additional information into existing systems, whether in the form of incidental observations or feedback on policy and strategy developments. The authorities need to take this seriously to maintain their legitimacy. Just like flood risks, data can be perceived and interpreted very differently by different users. Transparency on how data has been gathered, translated into information, for what purpose and for whose benefit is therefore crucial.

Notably, in both cases, the respective authorities are under the impression that most citizens perceive flood risk an issue that should be dealt with by the authorities, resulting in limited motivation for citizens to participate (with or without using specific ICT tools) in flood risk management. While the authorities may be responsible for flood risk management, they will not be able to prevent the occurrence of floods altogether. This realization may still need to sink in among citizens (but also among some authorities). The active involvement in citizen observatories as human sensors (providing intended and volunteered observations using sensor technologies or cameras) may be the necessary trigger for greater flood risk awareness and participation. So citizen observatories may be a useful means for awareness raising on flood risk issues among citizens, but more advanced levels of citizen participation in flood risk management are highly reliant on the role granted for citizens by the authorities.

\section{CONCLUSIONS}

In this paper, we examined a particular social innovation aspect (namely, eParticipation) of emerging citizen observatories that include the observations of ordinary citizens, and not just those of scientists and professionals, in earth observation and environmental conservation. We focused on two cases of the WeSenseIt project that is currently designing, implementing and validating citizen observatories of water (focused thus far on flood risk management).

In sum, given the institutional structures identified in these cases and the obligation of authorities to be accountable for their decisions, citizen observatories have the potential, but do not automatically imply, that citizens will become more active players in flood risk management, gaining participation with higher impact on decision making, nor that communication between stakeholders will improve. For some authorities, the involvement of citizens as human and social sensor in data capture may already be a major step while true co-participation in decision making seems (still) unthinkable. Careful integration of the interactive features of a citizen observatory with the existing institutional structures may help to strengthen flood risk management as well as citizen participation therein.
The potential social innovation outcome of citizen observatories in terms of participation will be achieved to a different extent and at a different pace from one implementation to another. While perceptions of success may differ, progressive improvements in participation and flood risk management via citizen observatories will definitely depend on both, authorities and citizens.

This paper has primarily focused on social innovation as a specific outcome of citizen observatories (i.e. the societal benefits in terms of eParticipation). At the same time, our discussion has also highlighted the process-like nature of social innovation, consisting of a combination of social and institutional changes to accompany the development and implementation of citizen observatories to result in the envisaged outcomes in terms of greater citizen participation.

Our conceptual approach of using the adjusted democracy cube has served us well by providing a multi-dimensional, yet manageable conceptual basis for analyzing and comparing the public participation dynamics across cases. However, caution needs to be taken with the interpretation of the illustrated findings. The resulting images of the adjusted democracy cube, although carefully devised based on the empirical evidence, are just that - illustrations - rather than portrayals of an objectively observable truth. Nevertheless, these illustrations serve as a useful communication tool among researchers, stakeholders and decision makers. Another limitation of this research is its focus on only two cases. Further investigation is required to confirm our findings, based on a larger number of cases. The study of other types of citizen observatories with a different focus (cf. classification citizen observatories by [3]) may yield interesting comparisons.

Finally, the citizen observatories of water studied here are evolving, in terms of the types and quantity of engaged citizens, and the developed and applied technologies. Subsequent phases of the action research reported on here will therefore serve to explore the role of the data and knowledge provided by citizens, the roles of citizens and authorities, and how the evolving citizen observatories result in social innovation, i.e. how citizen observatories can help to attract people to exercise their voting rights (e.g. as in the elections for the Dutch water boards), to give them a voice in flood risk management or whether they will exclude relevant stakeholders as in other instances of the digital divide.

\section{ACKNOWLEDGMENTS}

The research reported on in this paper is part of the WeSenseIt project which has received funding from the European Union under grant agreement No 308429.ect. (www.wesenseit.eu). We are thankful to all interviewees for their time and cooperation during the empirical research. We gratefully acknowledge the comments on an early version of this paper by our colleague Dr. Maria Rusca.

\section{REFERNCES}

[1] Y. Bhattacharjee, "Citizen scientists supplement work of Cornell researchers," Science, vol. 308, 2005, pp. 1402-1403. 
[2] J. Silvertown, "A new dawn for citizen science," Trends in Ecology \& Evolution, vol.24 (9), 2009, pp. 467-201.

[3] M. Goodchild, "Citizens as sensors: the world of volunteerd geography," GeoJournal, vol. 69, 207, pp. 211-221.

[4] C. Heipke, "Crowdsourcing geospatial data," ISPRS Journal of Photogrammetry and Remote Sensing, vol. 65, 2010, pp. 550557.

[5] A.T. Campbell, S.B. Eisenman, N.D. Lane, E. Miluzzo, R.A. Peterson, "People-centric urban sensing," Proceedings of 2nd ACM/IEEE Int'l Conf. on Wireless Internet, WICON'06, ACM Int'l Conf. Proc. Series, vol. 220, No. 18, Boston, Aug 2-5, 2006.

[6] J. Höller, V. Tsiatsis, C. Mulligan, S. Karnouskos, S. Avesand, D. Boyle, "Chapter 15 - Participatory Sensing," in From MachineTo-Machine to the Internet of Things, J. Höller, V. Tsiatsis, C. Mulligan, S. Karnouskos, S. Avesand, D. Boyle, Eds. Oxford: Academic Press, 2014, pp. 295-305.

[7] F. Ciravegna, H. Huwald, V. Lanfranchi, U. Wehn de Montalvo, "Citizen observatories: the WeSenseIt vision," INSPRIRE 2013 (Infrastructure for Spatial Information in the European Community), 23-27 June 2013.

[8] F. Moulaert, D. MacCallum, J. Hillier, "Social innovation: intuition, precept, concept, theory and practice," The International Handbook on Social Innovation - Collective Action, Social Learning and Transdisciplinary Research, F. Moulaert, D. MacCallum, A. Mehmood, A. Hamdouch, Eds. Cheltenham: Edward Elgar, 2013, pp. 13-24.

[9] OECD, "Fostering Innovation to Address Social Challenges," Paris: OECD Publishing, 2011.

[10] G. Mulgan, "Social Innovation - What it is, why it matters and how it can be accelerated," London: The Basingstoke Press, 2007.

[11] E. Pol, S. Ville, "Social innovation: Buzz word or enduring term?" Journal of Socio-Economics, vol. 38, 2009, pp. 878-885.

[12] A. Mehmood, C. Parra, "Social innovation in an unsustainable world," The International Handbook on Social Innovation Collective Action, Social Learning and Transdisciplinary Research, F. Moulaert, D. MacCallum, A. Mehmood, A. Hamdouch, Eds. Cheltenham: Edward Elgar, 2013, pp. 53-66.

[13] C. Freeman, L. Soete, "Work for All or Mass Unemployment: Computerised Technical Change into the 21st Century," London: Pinter Publishers, 1994.

[14] M.S. Reed, "Stakeholder participation for environmental management: A literature review," Biological Conservation, vol. 141(10), 2008, pp. 2417-2431.

[15] S. Arnstein, "A Ladder of Citizen Participation," Journal of the American Planning Association, vol. 35(4), 1969, pp. 216-224.

[16] A. Fung, "Varieties of Participation in Complex Governance", Public Administration Review, vol. 66, 2006, pp. 66-75.

[17] J.Q. Tritter, A. McCallum, "The snakes and ladders of user involvement: Moving beyond Arnstein," Health Policy, vol. 76(2), 2006, pp. 156-168.
[18] C. Sanford, J. Rose, "Charaterizing eParticipation," International Journal of Information Management, vol. 27, 2007, pp. 406421.

[19] Ø. Sæbo, J. Rose, L. Skiftenes Flak, "The shape of eParticipation: Characterizing an emerging research area," Government Information Quarterly, vol. 25, 2008, pp. 400-428.

[20] R. Medaglia, "eParticipation research: Moving characterization forward (2006-2011)," Government Information Quarterly, vol. 29, 2012, pp. 346-350.

[21] J. Pickles, (Ed.) "Ground Truth: the Social Implications of Geographic Information Systems," New York: Guildord Press, 1995.

[22] P. Jankowski, "Towards participatory geographic information systems for community-based environmental decision making," Journal of Environmental Management, vol. 90, 2009, pp. 1966-1971.

[23] M.K. McCall, "Seeking good governance in participatory-GIS: a review of processes and governance dimensions in applying GIS to participatory spatial planning," Habitat International, vol.27, 2003, pp. 549-573.

24] C. Seeger, "The role of facilitated volunteered geographic information in the landscape planning and site design process," GeoJournal, vol. 72(3-4), 2008, pp. 199-213.

[25] M.K. McCall, C.E. Dunn, "Geo-information tools for participatory spatial planning: Fulfilling the criteria for 'good' governance?" Geoforum, vol. 43, 2012, pp. 81-94.

[26] D. Alexander, "Principles of emergency planning and management," Harpenden, UK: Terra Publisher, 2002.

[27] Water Authority Delfland, Homepage Water Authority Delfland. http://www.hhdelfland.nl/algemeneonderdelen/serviceblok/english/. Visited April 15th 2013

[28] OECD, "Water Governance in the Netherlands," Paris: OECD Publishing, 2014

[29] V. Lanfranchi, S. Wrigley, N. Ireson, F. Ciravegna, U. Wehn, "Citizens' Observatories for Situation Awareness in Flooding," Proceedings of the 11th International ISCRAM Conference University Park, Pennsylvania, USA, May 2014, S.R. Hiltz, M.S. Pfaff, L. Plotnick, A.C. Robinson, Eds., in press.

[30] U. Wehn de Montalvo, J. Evers, M. Rusca, A. Onencan, V. Lanfranchi, F. Ciravegna, "Citizen observatories of water = participatory + improved governance?" INSPRIRE 2013 (Infrastructure for Spatial Information in the European Community), Florence, 23-27 June 2013. 